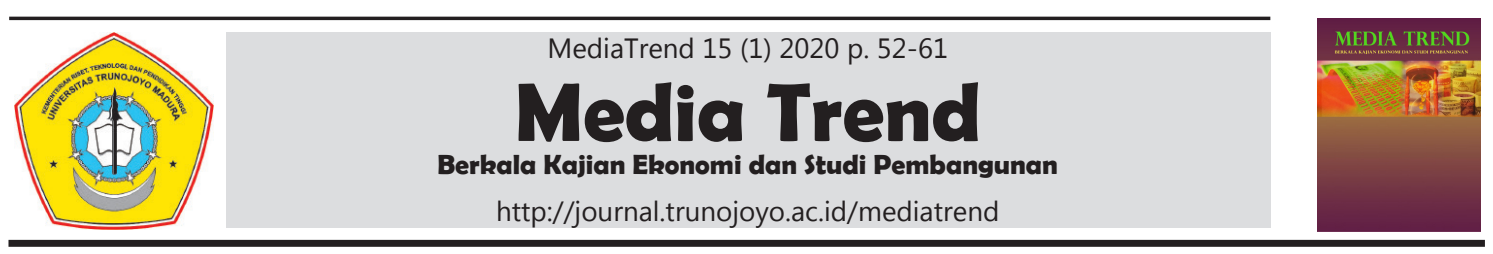

\title{
Analisis Pertumbuhan Ekonomi dan Indeks Pembangunan Manusia di Kabupaten/Kota Provinsi Bali (Metode Kointegrasi)
}

\author{
Muhammad Virgi Hariyanto $^{1^{*}}$, Putu Ayu Pramitha Purwanti $^{2}$ \\ 1,2 Universitas Udayana
}

\section{Informasi Artikel \\ Sejarah artikel: \\ Diterima Februari 2020 \\ Disetujui Februari 2020 \\ Dipublikasikan Maret \\ 2020}

\section{Keywords:}

Economic Growth,

HDI, Klassen Typology,

Cointegration

\begin{abstract}
A B S T R ACT
This study aims to analyze the long-term relationship between economic growth and the Bali Province HDI. The data used are panel data on economic growth and district / city level HDI in Bali Province for the period 2004-2017. The analysis used first, Klassen Typology, secondly cointegration,. With the stage of using the Unit Roots Test to test the stationarity of the variable. The results of the Klassen Typology show that Badung Regency, Denpasar City, and Gianyar Regency fall into the fast-growing and fast-growing regional category, Buleleng Regency falls into the fast-developing area category, Jembrana Regency and Tabanan Regency fall into the category of potential but depressed regions. Bangli Regency, Karangasem Regency, and Klungkung Regency fall into the relatively backward regional category. The results of the cointegration method show a long-term balance (cointegration) relationship between economic growth and HDI in Bali Province.
\end{abstract}

\section{A B S T R A K}

Penelitian ini bertujuan untuk menganalisis hubungan jangka panjang antara pertumbuhan ekonomi dan HDI Provinsi Bali. Data yang digunakan adalah data panel tentang pertumbuhan ekonomi dan IPM tingkat kabupaten/kota di Provinsi Bali untuk periode 2004-2017. Analisis yang digunakan pertama, Tipologi Klassen, kointegrasi kedua. Dengan tahap menggunakan unit roots test untuk menguji stasioneritas variabel. Hasil dari Tipologi Klassen menunjukkan bahwa Kabupaten Badung, Kota Denpasar, dan Kabupaten Gianyar termasuk dalam kategori daerah yang tumbuh cepat dan tumbuh cepat, Kabupaten Buleleng termasuk dalam kategori daerah yang berkembang cepat, Kabupaten Jembrana dan Kabupaten Tabanan termasuk dalam kategori daerah potensial tetapi tertekan. Kabupaten Bangli, Kabupaten Karangasem, dan Kabupaten Klungkung termasuk dalam kategori daerah yang relatif terbelakang. Hasil dari metode kointegrasi menunjukkan hubungan keseimbangan (kointegrasi) jangka panjang antara pertumbuhan ekonomi dan IPM di Provinsi Bali.

(C) 2020 MediaTrend

Penulis korespondensi:

E-mail: mvirgiyo@gmail.com

DOI: http://dx.doi.org/10.21107/mediatrend.v15i1.6746

2460-7649 (c) 2020 MediaTrend. All rights reserved. 


\section{PENDAHULUAN}

Era otonomi daerah ini, pemerintah khususnya di masing-masing provinsi di Indonesia dituntut untuk bisa mandiri dalam menjalankan perekonomiannya. Pemerintah diharapkan mampu untuk mengatasi setiap permasalahan yang ada di wilayah mereka masing-masing, dengan berbagai regulasi yang ada, maupun dengan tata cara penyelesaian masalah yang lain, dan inilah yang disebut juga otonomi daerah. Otonomi daerah pada dasarnya adalah hak, wewenang dan kewajiban daerah untuk mengatur dan mengurus rumah tangganya sendiri. Hak tersebut diperoleh melalui penyerahan urusan pemerintah dari pemerintah pusat kepada pemerintah daerah sesuai dengan keadaan dan kemampuan daerah yang bersangkutan (Wasingah, 2018).

Kebijakan desentralisasi dimulai sejak lama, yaitu sejak dikeluarkannya Undang-Undang No.1 Tahun 1945 tentang pembentukan Komite Nasional Indonesia Pusat, namun kebijakan desentralisasi di Indonesia memang baru diterapkan sejak 1 Januari 2001, yang ditandai dengan diberlakukannya Undang-Undang No.22 Tahun 1999 tentang Pemerintahan Daerah yang kemudian diubah dengan Undang-Undang No.32 Tahun 2004. Sejak diberlakukannya kebijakan desentralisasi, pemerintah daerah telah menjadi pemain utama dalam pembangunan daerah (Renggo, 2015).

Otonomi daerah juga dapat diartikan sebagai cara untuk meningkatkan kesejahteraan masyarakat melalui layanan-layanan publik serta fasilitas-fasilitas umum yang menunjang kemakmuran masyarakat (Rustariyuni, 2013). Tujuan campur tangan pemerintah yaitu untuk menjamin agar kesamaan hak setiap individu, menjaga agar perekonomian dapat tumbuh dan mengalami perkembangan yang teratur serta stabil, mengawasi kegiatan-kegiatan perusahaan, menyediakan barang publik dan mengawasi terjadinya eksternalitas kegiatan ekonomi yang merugikan masyarakat (Hamid, 2015). Pembangunan ekonomi daerah adalah suatu proses adanya kerjasama yang dilakukan antara pemerintah dengan masyarakat di daerah. Pengeluaran yang dilakukan pemerintah menunjukkan perannya dalam perekonomian untuk mencapai kondisi masyarakat yang sejahtera (Linda, 2016).

Provinsi Bali sebagai salah satu provinsi yang menjalankan otonomi daerah merupakan salah satu provinsi yang mempunyai keragaman dari segi sumber daya alam maupun sumber daya manusianya (Artini, 2017). Faktanya, pertumbuhan ekonomi di Kabupaten/Kota Provinsi Bali masih belum merata. Jika dilihat dalam

Tabel 1

Pertumbuhan Ekonomi di Kabupaten/Kota Provinsi Bali tahun 2013-2017 (\%)

\begin{tabular}{lccccc}
\hline Kabupaten / Kota & $\mathbf{2 0 1 3}$ & $\mathbf{2 0 1 4}$ & $\mathbf{2 0 1 5}$ & $\mathbf{2 0 1 6}$ & $\mathbf{2 0 1 7}$ \\
\hline Jembranaa & 5,69 & 6,05 & 6,23 & 5,96 & 6,11 \\
Tabanan & 6,45 & 6,53 & 6,19 & 6,14 & 5,58 \\
Badung & 6,82 & 6,98 & 6,24 & 6,81 & 6,11 \\
Gianyar & 6,82 & 6,80 & 6,30 & 6,31 & 5,50 \\
Klungkung & 6,05 & 5,98 & 6,11 & 6,28 & 5,34 \\
Bangli & 5,94 & 5,83 & 6,22 & 6,23 & 5,35 \\
Karangasem & 6,16 & 6,01 & 6,00 & 6,31 & 5,08 \\
Buleleng & 7,15 & 6,96 & 6,12 & 6,02 & 5,40 \\
Denpasar & 6,69 & 7,00 & 6,14 & 6,51 & 6,08 \\
\hline Bali & 6,69 & 6,73 & 6,03 & 6,32 & 5,59 \\
\hline
\end{tabular}

Sumber Data: BPS Provinsi Bali 2017 
pertumbuhan 5 tahun terakhir Kabupaten/ Kota di Provinsi Bali masih berfluktuasi, ada yang lebih rendah dan juga ada yang lebih tinggi dibandingkan tingkat pertumbuhan Provinsi Bali.

Tabel 1 menunjukkan Kabupaten Bangli memiliki tingkat pertumbuhan ekonomi terendah pada tahun 2013 dengan angka $5.94 \%$ dari keseluruhan wilayah yang ada, dan menglami fluktuasi dari tahun ke tahun. Tingkat pertumbuhan ekonomi rendah tahun 2017 terjadi pada Kabupaten Karangasem dengan angka 5.08\%. Pertumbuhan di Kabupaten Badung juga masih cenderung konstans dalam angka $6 \%$. Pertumbuhan ekonomi yang tinggi dan proses pembangunan berkelanjutan merupakan kondisi utama bagi kelangsungan perkembangan ekonomi daerah (Renggo, 2015).

Tidak stabilnya pertumbuhan ekonomi di tiap Kabupaten/Kota di Provinsi Bali menimbulkan tanda tanya besar bagi pemerintahan yang sekiranya kurang efisien dan efektif dalam menjalankan pembangunan ekonomi daerah. Hal itu bisa dilihat pada tahun 2017 angka pertumbuhan ekonomi Provinsi Bali menurun cukup drastis, dari $6.32 \%$ pada tahun 2016 menjadi 5.59\% ditahun 2017. Seperti yang disebutkan Hidayat (2010), tingginya pertumbuhan ekonomi suatu wilayah menan- dakan semakin baik kegiatan-kegiatan atau kinerja ekonomi daerah yang dapat dilihat dari pertumbuhan pendapatan.

Sejalan dengan berjalanannya waktu, disadari bahwa pertumbuhan ekonomi yang tinggi tidak serta merta dapat mengatasi permasalahan sosial ekonomi seperti masalah pengangguran, kemiskinan di perdesaan, distribusi pendapatan yang timpang, dan diperlukan ide keadilan sosial dalam perkembangan ekonomi setiap wilayah (Barros, 2015; Tiwari dan Shahbaz, 2013). Hal ini memperkuat keyakinan bahwa pertumbuhan ekonomi merupakan syarat yang diperlukan (necessary), tetapi tidak mencukupi (sufficient) bagi proses pembangunan (Ahmed dan Wahid, 2011). Tujuan pembangunan tersebut, munculah konsep pembangunan manusia. Pembangunan manusia ialah suatu proses memperluas pilihan-pilihan penduduk (a process Enlarging people's choices). Ada tiga pilihan yang dianggap paling penting, yaitu panjang umur dan sehat (longevity), berpendidikan/berpengetahuan (knowledge), dan akses ke sumber daya yang dapat memenuhi standar hidup yang layak (living standard).

Berdasarkan beberapa aspek tersebut, UNDP (United Nation Development Programme) telah menetapkan standar pengukuran pembangunan sumber

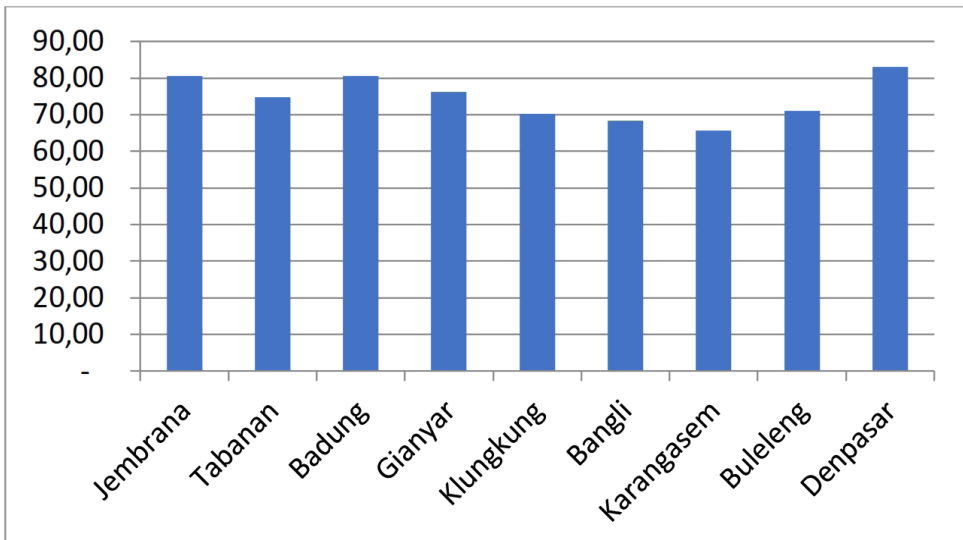

Gambar 1.

Indeks Pembangunan Manusia di Kabupaten/Kota Provinsi Bali tahun 2017 Sumber Data: BPS Provinsi Bali 2017 
daya manusia yang dituangkan ke dalam Human Development Indeks (HDI) atau Indeks Pembangunan Manusia (IPM). Indeks tersebut merupakan salah satu indikator untuk mengukur taraf kualitas fisik dan non fisik penduduk (Sudibia dan Marhaeni, 2013). Kualitas fisik tercermin dari angka harapan hidup sedangkan kualitas non fisik melalui lamanya ratarata penduduk bersekolah dan angka melek huruf. IPM juga merupakan salah satu indikator terciptanya pembangunan yang mampu mendorong pertumbuhan ekonomi (Wasingah, 2018).

Gambar 1 menunjukkan bahwa nilainya tingkat IPM dari masyarakat Provinsi Bali beberapa sudah mencapai angka diatas 60 poin yang berarti golongan menengah atau sedang. Golongan menengah yang dimaksud adalah golongan yang memiliki status pembangunan sedang dalam artian di batas rata-rata. Namun demikian, Kabupaten Badung dan wilayah Kotamadya Denpasar memiliki tingkat IPM yang tergolong tinggi karena angkanya diatas 80 poin pada tahun 2017. Ini menyimpulkan bahwa Provinsi Bali bagian selatan lebih baik dalam segi pembangunan manusianya dibanding dengan Provinsi Bali bagian Utara, dan ini menjadi konsern utama bagi peneliti untuk melihat hubungan jangka Panjang antara pertumbuhan ekonomi dengan tingkat IPM disetiap Kabupaten/Kota Provinsi Bali.

Pembangunan manusia yang dikonsepkan melalui Indeks Pembangunan Manusia juga sepertinya belum berjalan sebagaimana mestinya di Provinsi Bali, dengan tingkatan angka yang diperoleh dari BPS Provisi Bali (2018) masih terjadi ketimpangan di beberapa Kabupaten/Kota. Pertumbuhan ekonomi seharusnya meningkatkan persediaan sumberdaya yang dibutuhkan untuk pembangunan manusia (Dar dan Asif, 2018). Alokasi sumberdaya yang tepat serta distribusi peluang yang semakin luas, khususnya kesempatan kerja akan mendorong pembangunan manu- sia lebih baik. Hal ini akan berimbas pada pembangunan manusia yang mendorong peningkatan pertumbuhan ekonomi, karena tingkat pembangunan manusia yang tinggi sangat menentukan kemampuan penduduk dalam menyerap dan mengelola sumber-sumber pertumbuhan ekonomi, baik kaitannya dengan teknologi maupun terhadap kelembagaan sebagai sarana penting untuk mencapai pertumbuhan ekonomi (Wijantari dkk, 2016).

Hubungan jangka panjang antara pertumbuhan ekonomi dan IPM diperkuat dengan penelitian yang dilakukan oleh Gabiraldi dan Hidayat (2015), dengan hasil menunjukkan bahwa terdapat hubungan keseimbangan jangka panjang antara pertumbuhan ekonomi dan indeks pembangunan manusia provinsi-provinsi di Indonesia. Selanjutnya, diperkuat pula dengan penelitian lain yang dilakukan oleh Maratade, Rotinsulu, dan Niode (2016), yang mengatakan bahwa ketika pertumbuhan ekonomi mengalami perubahan (peningkatan ataupun penurunan) maka hal tersebut akan mempengaruhi indeks pembangunan manusia dan sebaliknya ketika indeks pembangunan manusia mengalami perubahan (peningkatan atau pun penurunan) maka hal tersebut akan mempengaruhi pertumbuhan ekonomi di wilayah Provinsi Sulawesi Utara. Adapun penelitian yang dilakukan oleh Sethi dan Acharya (2018), mengatakan Financial Inclusion (FI) atau inklusi finansial mempunyai pengaruh positif jangka panjang terhadap pertumbuhan ekonomi di India.

\section{METODE PENELITIAN}

Pendekatan yang digunakan dalam penelitian ini yaitu pendekatan kuantitatif dengan jenis penelitian menurut tingkat eksplanasinya yakni hubungan korelasi. Lokasi pada penelitian ini adalah di Provinsi Bali, karena provinsi memiliki keragaman dari segi ekonomi, dan inilah yang membuat peneliti memilih lokasi di Provinsi Bali untuk mengetahui keraga- 
man sosial ekonomi tersebut apakah bisa saling mempengaruhi satu dengan lainnya. Objek penelitian yang digunakan dalam penelitian ini adalah Pertumbuhan Ekonomi dan juga tingkat IPM se Kabupaten/ Kota di Provinsi Bali dari tahun 2004-2017. Jenis data yang digunakan dalam penelitian ini terdiri dari data kuantitatif. Teknik analisis data menggunakan tipologi klassen, uji akar unit, dan uji kointegrasi. Untuk dapat membandingkan tingkat kemajuan suatu daerah dengan daerah lain dalam suatu lingkup referensi yang sama, maka dapat digunakan Tipologi Klassen sebagai alat analisis. diamati dapat dibagi menjadi empat klasifikasi, yaitu: (1) daerah dengan pertumbuhan ekonomi dan pembangunan manusia yang tinggi. Daerah ini dikategorikan daerah cepat maju dan cepat tumbuh (kuadran I), (2) daerah dengan pertumbuhan ekonomi tinggi, namun pembangunan manusianya rendah. Daerah ini dikategorikan daerah cepat berkembang (kuadran II), (3) daerah dengan pembagunan manusia tinggi namun pertumbuhan ekonominya rendah. Daerah ini dikategorikan daerah potensial namun tertekan (kuadran III), (4) daerah relatif tertinggal, baik dalam pertumbuhan ekonomi maupun pembangunan manusia.

Tabel 2.

Klasifikasi Daerah Menurut Tipologi Klassen

\begin{tabular}{|c|c|c|}
\hline rly & $y_{i}<y$ & $y_{i}>y$ \\
\hline$r_{i}<r$ & $\begin{array}{c}\text { Kuadran II } \\
\text { Daerah cepat berkembang }\end{array}$ & $\begin{array}{c}\text { Kuadran I } \\
\text { Daerah cepat maju dan cepat } \\
\text { tumbuh }\end{array}$ \\
\hline$r_{i}>r$ & $\begin{array}{c}\text { Kuadran IV } \\
\text { Daerah relatif tertinggal }\end{array}$ & $\begin{array}{c}\text { Kuadran III } \\
\text { Daerah tertekan }\end{array}$ \\
\hline
\end{tabular}

$r_{i}$ adalah laju pertumbuhan ekonomi wilayah i, $y_{i}$ adalah IPM wilayah I, $r$ adalah laju pertumbuhan ekonomi wilayah referensi, dan y adalah IPM wilayah referensi. Tipologi Klassen melakukan pengolompokan wilayah berdasarkan dua karakteristik yang dimiliki daerah tersebut yaitu Indeks Pembangunan Manusia (IPM) dan laju pertumbuhan ekonomi. Melalui analisis ini diperoleh empat karateristik pola dan struktur pertumbuhan ekonomi yang berbeda, yaitu: daerah pertumbuhan cepat, daerah sedang tumbuh, daerah tertekan dan daerah relatif tertinggal. Tipologi Klassen digunakan untuk mengidentifikasi sektor subsektor atau unggulan suatu daerah, dalam hal ini tipologi klassen dilakukan untuk membagi daerah berdasarkan dua indikator utama, yaitu pertumbuhan ekonomi dan IPM.

Rata-rata pertumbuhan ekonomi sebagai sumbu vertikal dan rata-rata IPM sebagai sumbu horizontal, daerah yang
Daerah ini dikategorikan daerah relatif tertinggal (kuadran IV). (Gabiraldi dan Hidayat, 2015)

Apakah data panel yang digunakan stasioner atau tidak stasioner, salah satu caranya yang dapat dilakukan adalah menggunakan uji akar unit (unit root test). Data panel merupakan gabungan antara data time series dan cross section, maka tahap uji stasioner juga perlu dilakukan. Ada perbedaan uji stasioner di data panel dengan uji stasioner di data time series, hal ini dikarenakan adanya pengaruh individual dan waktu. Ide dasar uji unit root dalam data panel adalah pengembangan dari uji unit root dalam times series, yang dapat dijelaskan dalam model:

$Y_{i t}=\rho_{t}+x_{i t}+\delta_{i t}+\varepsilon_{i t}$

Dimana i adalah jumlah individu, sedangkan $t$ adalah jumlah periode individu, jika 
diasumsikan $\alpha=\rho-1$ dengan lag $P i$ dan bervariasi antar cross section, maka uji hipotesisnya:

$\mathrm{H} 0: \alpha=0$ (mempunyai akar unit)

$\mathrm{H} 1: \alpha<0$ (tidak mempunyai akar unit)

Jika nilai $\rho t=1$ maka dikatakan bahwa variabel random $Y$ mempunyai akar unit (unit root). Jika data panel mempunyai akar unit maka dikatakan data tersebut bergerak secara acak (random walk) dan data yang mempunyai sifat random walk dikatakan data tidak stasioner. Oleh karena itu jika kita melakukan regresi $Y_{i t}$ pada lag $Y_{\text {it-1 }}$ dan mendapatkan nilai $\rho t=$ 1 maka dikatakan tidak stasioner. Inilah ide dasar uji akar unit untuk mengetahui apakah data stasioner atau tidak. Formula uji unit root dengan dasar ADF adalah:

$Y_{i t}=\alpha Y_{i t-1}+\sum_{f=1}^{F i} \beta_{t f} \Delta Y_{i t}+X_{i t}^{1} \delta+\varepsilon_{i t}$

Jika diasumsikan $\alpha=\rho-1$ dengan lag $P_{i}$ dan bervariasi antar cross section, maka uji hipotesisnya:

$\mathrm{HO}: \alpha=0$ (mempunyai akar unit) $\mathrm{H} 1: \alpha<0$ (tidak mempunyai akar unit)

Prosedur untuk menentukan apakah data stasioner atau tidak dengan cara membandingkan antara nilai statistik dengan nilai kritisnya. Jika nilai absolut statistik lebih besar dari nilai kritisnya, maka data yang diamati menunjukkan stasioner dan jika sebaliknya, nilai absolut statistik lebih kecil dari nilai kritisnya maka data tidak stasioner.

Kointegrasi adalah suatu hubungan jangka panjang antara variabelvariabel yang meskipun secara individual tidak stasioner, tetapi kombinasi linear antara variabel tersebut menjadi stasioner dan kita bisa menguji kemungkinan kointegrasinya sambal memperkirakan hubungan jangka panjangnya (Teles \& Mussolini, 2012; Darrat \& Zhong, 2002;
Dario \& Deisell, 2015). Untuk mengetahui pola interaksi antara seri data yang dapat dilihat, tes kausalitas Granger dilakukan selanjutnya. Metode yang dapat digunakan untuk melakukan uji kointegrasi adalah pengembangan dari uji kointegrasi di data time series, seperti metode yang menggunakan dasar test kointegrasi Engle-Granger dan Combined individual test Fisherl Johansen (Misra \& Trivedi, 2002; Muhammad Adnan Hye \& Dolgopolova, 2011).

Adapun formula regresi untuk melakukan uji kointegrasi yaitu:

$Y_{i t}=\alpha_{t}+\beta_{1 t} X_{1 i t}+\varepsilon_{i t}$

Dimana $Y_{\text {it }}$ adalah pertumbuhan ekonomi, at adalah konstanta, $\beta_{1 \mathrm{t}}$ adalah koefisien, $X_{1 i t}$ adalah indeks pembangunan manusia, zit adalah eror. Kemudian kita dapatkan residualnya:

$\varepsilon_{i t}=\rho_{i t} \varepsilon_{i t-1}+u_{i t}$

atau

$\varepsilon_{i t}=\rho_{i t} \varepsilon_{i t-1}+\sum_{f=1}^{p i} \varphi_{i t}+\Delta \varepsilon_{i t-1}+u_{i t}$

Dari hasil estimasi nilai statistiknya, kemudian dibandingkan dengan nilai kritisnya. Nilai statistik diperoleh dari nilai pt. Jika nilai statistiknya lebih besar dari nilai kritisnya maka variabel-variabel yang diamati saling berkointegrasi atau mempunyai hubungan jangka panjang dan sebaliknya, maka variabel-variabel yang diamati tidak berkointegrasi.

\section{HASIL ANALISIS DAN PEMBAHASAN}

Gambar 2 menunjukan hasil Tipologi Klassen pengolompokan wilayah berdasarkan dua karakteristik yang dimiliki daerah tersebut yaitu Indeks Pembangunan Manusia (IPM) dan laju pertumbuhan ekonomi. Pada gambar tersebut dapat dilihiat bahwa Kota Denpasar, Kabupaten Badung, dan Kabupaten Gianyar masuk ke dalam kuadran I atau dengan kata lain 


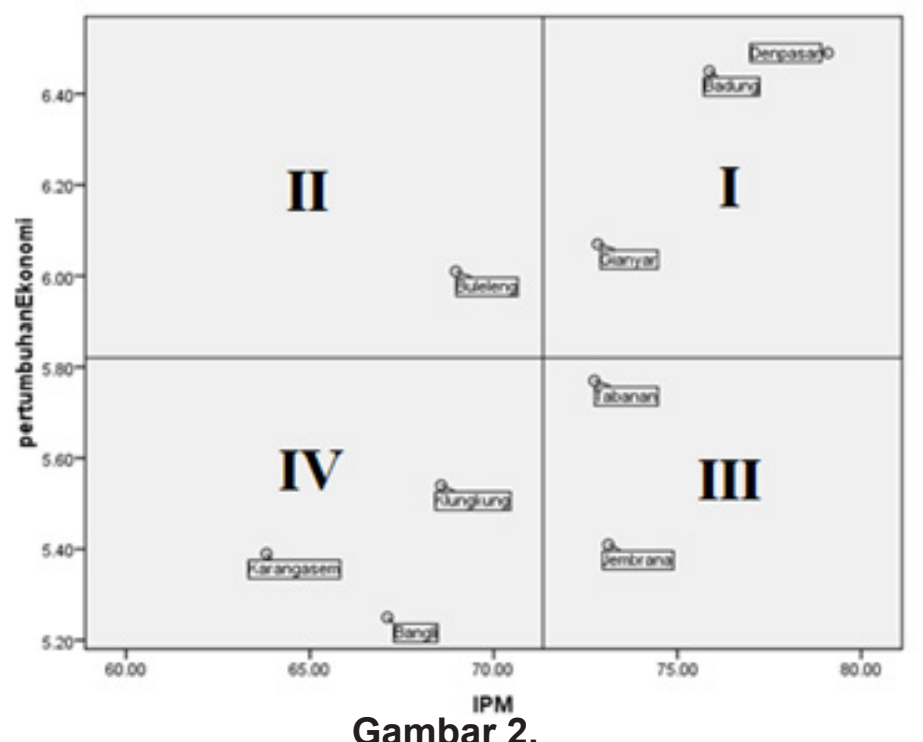

Hasil Tipologi Klassen Pertumbuhan Ekonomi dan IPM di Kabupaten/Kota Provinsi Bali 2004 - 2017

merupakan daerah yang cepat maju dan cepat tumbuh. Pada kuadran selanjutnya yaitu kuadran II terdapat Kabupaten Buleleng, dengan kata lain Kabupaten Buleleng dapat digolongkan sebagai kabupaten yang cepat berkembang.

Pada kuadran III terdapat Kabupaten Jembrana dan Kabupaten Tabanan dimana kedua daerah ini dapat digolongkan sebagai daerah dengan sektor potensial atau masih dapat berkembang dengan pesat namun tertekan. Pada kuadran IV terdapat Kabupaten Bangli, Kabupaten Karangasem, dan Kabupaten Klungkung yang mana ketiga kabupaten ini digolongkan sebagai kabupaten yang relatif tertinggal.

Tabel 3 menunjukkan hasil uji akar unit pada variabel IPM dan PDRB di Kabupaten/Kota Provinsi Bali. Uji ini digunakan untuk menguji kestationeran dari tiap-tiap variabel terkait.

Tabel 3.

Hasil Uji Akar Unit Pertumbuhan Ekonomi dan IPM Kabupaten/Kota Provinsi Bali $2004-2017$

\begin{tabular}{lcc}
\hline \multicolumn{1}{c}{ Method } & Statistic & Prob. $^{* *}$ \\
\hline ADF - Fisher Chi-square & 72.1993 & 0.0000 \\
ADF - Choi Z-stat & -6.26167 & 0.0000 \\
\hline
\end{tabular}

Variabel Produk Domestik Regional Bruto (PDRB)

\begin{tabular}{lcc}
\hline \multicolumn{1}{c}{ Method } & Statistic & Prob. $^{* *}$ \\
\hline ADF - Fisher Chi-square & 73.0769 & 0.0000 \\
ADF - Choi Z-stat & -5.65080 & 0.0000 \\
\hline
\end{tabular}

Sumber : Hasil Olah Data, 2019 
Berdasarkan tabel hasil uji akar unit untuk data panel pada variabel Indeks Pembangunan Manusia (IPM), ditunjukkan bahwa variabel Indeks Pembangunan Manusia memiliki koefisien sebesar 72.1993 dengan probabilitas lebih kecil dari 0.05 maka null hypothesis yang menyatakan bahwa data tidak stationer ditolak. Begitu pula dengan variabel PDRB yang memiliki koefisien 73.0769 dengan probabilitas lebih kecil dari 0.05 sehingga null hypothesis juga ditolak, dengan demikian dapat diketahui bahwa variabel PDRB adalah stationer atau tidak memiliki akar unit. Variabel IPM dan PDRB yang telah diuji kestationerannya dapat dinyatakan telah stationer pada derakar integrasi yang sama. Variabel IPM dan PDRB telah stationer pada derajat integrasi pertama (I). Tabel 4 menunjukkan hasil uji kointegrasi Pertumbuhan Ekonomi dan IPM di Kabupaten/Kota Provinsi Bali. Uji ini dilakukan untuk mengetahui ada tidaknya hubungan jangka Panjang dari kedua variabel tersebut. koefisien kointegrasi dengan menggunakan Panel PP-Statistic sebesar -2.192662 dan koefisien Panel ADF-Statistic sebesar -2.613870. Probabilitas dari setiap metode pengujian menunjukkan bahwa variabel yang digunakan dalam penelitian yakni IPM dan PDRB saling berkointegrasi pada tingkat signifikansi $5 \%$ kecuali pada pengujian dengan Panel v-Statistic dan $\mathrm{Pa}-$ nel rho-Statistic.

Hasil uji panel kointegrasi dengan pendekatan parametrics, telah ditunjukkan bahwa Group rho-Statistic memiliki koefisien kointegrasi sebesar 0.484657 , Group PP-Statistic memiliki koefisien kointegrasi -1.225835, dan Group ADF-Statistic memiliki koefisien kointegrasi sebesar -1.701773. Probabilitas dari setiap metode pengujian menunjukkan bahwa variabel yang digunakan dalam penelitian yakni IPM dan PDRB saling berkointegrasi pada tingkat signifikansi $5 \%$ kecuali pada pengujian dengan Group rho-Statistic dan Group PP-Statistic. Berdasarkan hasil uji

Tabel 4.

Hasil Kointegrasi Pertumbuhan Ekonomi dan IPM di Kabupaten/Kota Provinsi Bali $2004-2017$

\begin{tabular}{|c|c|c|c|c|}
\hline \\
\hline \multicolumn{5}{|c|}{$\begin{array}{r}\text { Alternative hypothesis: common AR coefs. (within-dimension) } \\
\text { Weighted }\end{array}$} \\
\hline & Statistic & Prob. & Statistic & Prob. \\
\hline Panel v-Statistic & 0.810123 & 0.2089 & 0.677224 & 0.2491 \\
\hline Panel rho-Statistic & -1.176680 & 0.1197 & -0.998790 & 0.1589 \\
\hline Panel PP-Statistic & -2.192662 & 0.0142 & -1.876708 & 0.0303 \\
\hline Panel ADF-Statistic & -2.613870 & 0.0045 & -2.113938 & 0.0173 \\
\hline
\end{tabular}

Alternative hypothesis: individual AR coefs. (between-dimension)

\begin{tabular}{lcc} 
& Statistic & Prob. \\
\cline { 2 - 3 } Group rho-Statistic & 0.484657 & 0.6860 \\
Group PP-Statistic & -1.225835 & 0.1101 \\
Group ADF-Statistic & -1.701773 & 0.0444 \\
\hline & Sumber : Hasil Olah Data, 2019
\end{tabular}

Berdasarkan hasil uji panel kointegrasi dengan pendekatan non parametrics, telah ditunjukkan bahwa Panel $v$-Statistic memiliki koefisien kointegrasi sebesar 0.810123 sedangkan Panel rhoStatistic memiliki koefisien kointegrasi sebesar -1.176680. Selain itu, terdapat yang telah dilakukan dapat ditarik kesimpulan bahwa tiga panel dari total tujuh panel penelitian menunjukkan bahwa PDRB dan IPM saling berkointegrasi atau mempunyai hubungan jangka panjang, hal tersebut dikarenakan dalam setiap periode jangka pendek, variabel cenderung untuk saling 
menyesuaikan guna mencapai ekuilibrium jangka panjangnya.

Berdasarkan hasil penelitian yang telah dilakukan, kointegrasi yang terjadi antara Pertumbuhan Ekonomi dengan Indeks Pembangunan Manusia harus selaras dengan fakta-fakta ketimpangan yang terjadi di beberapa wilayah Provinsi Bali. Klasifikasi wilayah Kabupaten/Kota di Provinsi Bali dapat menunjukkan bahwa sektor-sektor unggulan ditiap-tiap wilayah masih belum diolah dengan optimal, pun berkaitan dengan kontribusi terhadap perbaikan kualitas sarana pendidikan, kesehatan, dan lapangan pekerjaan guna menunjang Pertumbuhan Ekonomi yang inklusif serta Indeks Pembangunan Manusia yang baik kiranya belum terlalu berjalan baik. Kemajuan yang terjadi dalam aspek Pertumbuhan Ekonomi dan IPM hanya terpusat dalam 3 wilayah yaitu Kota Denpasar, Kabupaten Badung dan Kabupaten Gianyar, sisanya masih terdapat ketimpangan di tiap-tiap wilayah. Dengan membuat program pembangunan yang berfokus pada pembangunan manusia, dengan lebih menjurus pada perbaikan kualitas sumber daya manusia diharapkan dapat berpangaruh banyak terhadap peningkatan IPM di Kabupaten/Kota Provinsi Bali dan dapat menghidupi sektor-sektor perekonomian di tiap-tap wilayah dengan merata sehingga manfaat dari pembangunan ekonomi dapat dirasakan semua pihak.

\section{SIMPULAN}

Kesimpulan yang diperoleh yaitu, berdasarkan tipologi Klassen, daerah yang digolongkan maju pesat yaitu Kota Denpasar, Kabupaten Badung, dan Kabupaten Gianyar. Daerah yang masuk ke dalam kategori daerah cepat berkembang yaitu Kabupaten Buleleng. Daerah yang digolongkan memeiliki potensi untuk berkembang yaitu Kabupaten Tabanan dan Kabupaten Jembrana. Sementara daerah yang dikategorikan sebagai daerah relatif tertinggal yaitu Kabupaten Klungkung, Kabupaten Bangli, dan Kabupaten Karangasem. Berdasarkan hasil uji yang telah dilakukan dapat ditarik kesimpulan menunjukkan bahwa PDRB dan IPM saling berkointegrasi atau mempunyai hubungan jangka panjang. Hal tersebut dikarenakan dalam setiap periode jangka pendek, variabel cenderung untuk saling menyesuaikan guna mencapai ekuilibrium jangka panjangnya. Saran dari penulis berdasarkan penelitian yaitu, sebaiknya bagi daerah yang termasuk dalam kategori potensial namun tertekan dan kategori relatif tertinggal, harus lebih mendalami atau mengevaluasi apa-apa saja komoditas yang dapat dijadikan sektor unggulan untuk menunjang dan meningkatkan roda perekonomian serta pemanfaatan sumber daya manusia yang ada. Begitu juga daerah yang kiranya sudah masuk dalam kategori berkembang dan maju, sebaiknya turut ikut andil dalam membantu mensejahterakan daerah lain dengan berbagai cara seperti ide, gagasan, konsep pembangunan yang baik, dan sebagainya.

\section{DAFTAR PUSTAKA}

Ahmed, A. D., and Wahid, A. N. M. (2011). Financial Structure And Economic Growth Link In African Countries: A Panel Cointegration Analysis. Journal of Economic Studies, 38(3): 331-357.

Artini, Ni Wayan Eka Surya., I Putu Eka Nila Kencana., Ketut Jayanegara. (2017). Model Tingkat Kemiskinan Di Kabupaten Bangli Dengan Pendekatan Partial Least Square. E-Jurnal Matematika, 6 (3):188-195.

Barros, P. P. (2015). Article Information: Advances in Health Economics and Health Services Research, 22: 3-27.

Dar, J. A., and Asif, M. (2018). Does Financial Development Improve Environmental Quality In Turkey? An Application Of Endogenous Structural Breaks Based 
Cointegration Approach. Management of Environmental Quality: An International Journal, 29(2): 368-384.

Dario Pranckevicius, Deisell M. Diaz, H. G. (2015). A Lean Six Sigma Case Study: An Application of the " $5 \mathrm{~s}$ " Techniques. Journal of Advances in Management Research, 5(1):63-79

Darrat, A. F., Hsu, M. K., \& Zhong, M. (2002). Foreign Trade, Human Capital and Economic Growth in Taiwan: A Reexamination. Studies in Economics and Finance, 20(1): 85-94.

Gabiraldi, Muhammad dan Hidayat, Paidi (2015). Analisis Hubungan IPM Dan Pertumbuhan Kabupaten/Kota Di Provinsi Sumatera Utara. Jurnal Ekonomi dan Keuangan, 2(2): 562-572.

Hamid, A. (2015). Analisis Variabel Pembangunan Ekonomi Dan Sosial Daerah Provinsi Sumatera Selatan Periode 1980-2013 (Sebuah Kajian Dengan Pendekatan Ecm Dan Vecm). Jurnal Esensi, 4(1): 1-20.

Hidayat, P. (2010). Analisis Kausalitas dan Kointegrasi antara Jumlah Uang Beredar, Inflasi dan Pertumbuhan Ekonomi Indonesia. Jurnal Ekonom, 13(1): 27-35.

Linda, R. (2016). Kausalitas Dan Kointegrasi Antara Pengeluaran Pemerintah Dan Pertumbuhan Ekonomi Kurun Waktu 1983-2014. Jurnal Penelitian Sosial Keagamaan. 19(2): 263-278

Maratade, S. Y., Rotinsulu, D. C., Niode, A. O., Pembangunan, J. E., Ekonomi, F., dan Bisnis, D. (2016). Analisis Pertumbuhan Ekonomi Dan Indeks Pembangunan Manusia Di Provinsi Sulawesi Utara (Studi Pada Tahun 2002-2013). Jurnal Berkala IImiah Efisiensi, 16(01): 328-338.

Misra, S. R., and Trivedi, M. (2002). A Cointegration Analysis of Demand:
Implications For Pricing. Journal Of Pricing Strategy and Practice, 5(4): 156-163.

Muhammad Adnan Hye, Q., \& Dolgopolova, I. (2011). Economics, Finance And Development In China. Journal Of Chinese Management Studies, 5(3): 311-324.

Renggo, Y. R. (2015). Kausalitas Antara Pertumbuhan Ekonomi Dan Kemiskinan Di Provinsi Nusa Tenggara Timur Tahun 2002 - 2015. Jurnal Ekonomi dan Kewirausahaan, 11(1): 35-46.

Sethi, D., and Sethy, S. K. (2019). Financial Inclusion Matters For Economic Growth In India: Some Evidence From Cointegration Analysis. International Journal of Social Economics, 46(1): 132-151.

Sudibia, I Ketut., dan Marhaeni, Anak Agung Istri Ngurah. 2013. Beberapa Strategi Pengentasan Kemiskinan Di Kabupaten Karangasem, Provinsi Bali. Piramida 9(1):1 -14.

Teles, V. K., and Mussolini, C. C. (2012). Infrastructure And Productivity In Latin America: Is There A Relationship In The Long Run? Journal of Economic Studies, 39(1): 44-62.

Tiwari, A. K., Shahbaz, M., and Islam, F. (2013). Does Financial Development Increase Rural-Urban Income Inequality? : Cointegration Analysis In The Case Of Indian Economy. International Journal of Social Economics, 40(2): 151-168.

Wasingah, Siti. (2018). Analisis Pertumbuhan Ekonomi Di Provinsi Jawa Tengah Tahun 2011-2015. Jurnal Universitas Islam Indonesia. Hal: 1-32.

Wijantari, Ni Made Wahyu., I Komang Gde Bendesa. (2016). Kemiskinan Di Provinsi Bali (Studi Komparatif Kabupaten/Kota Di Provinsi Bali). Jurnal Buletin Studi Ekonomi, 21(1): 13-25 